\title{
Implementasi Kebijakan Hutan Pendidikan (Studi pada Dusun Sumbersari, Desa Tawangargo, Malang)
}

\author{
Anna Fiulaizi a*, Sujarwoto ${ }^{\text {b }}$, I Gede Eko Putra Sri Sentanu ${ }^{\text {c }}$ \\ ${ }^{a b c}$ Universitas Brawijaya, Malang, Jawa Timur, Indonesia
}

INFORMASI ARTIKEL

Article history:

Dikirim tanggal: 28 April 2021

Revisi pertama tanggal: 26 Maret 2021

Diterima tanggal: 29 Maret 2021

Tersedia online tanggal: 14 April 2021

Keywords: policy implementation, educational Forest, UB Forest

\section{ABSTRACT}

This paper aims to explain and analyze the implementation of educational forest policy with the implementation model as administrative and political process from Grindle (1980), study on the UB Forest employee forest. The results of this study indicate that the implementation of education forest policy in UB forest is still difficult and be potential for failure. The failure is due to the achievement of the objectives of UB Forest, the program of activities which have not been carried out according to the programs design, and have not yet impacted to social group. This is influenced by various aspects of both the contents of the policy, which includes a) the interests affected; b) type of benefits; c) extend of change envision; d) site of decision making; e) program implementor, and f) resources committed, and the contect of implementation, which includes three (3) aspects; a) power, interests and strategies of the actors involved; b) institutionand regime characteristic; c) compliance and responsiveness.

\section{INTISARI}

Penelitian ini bertujuan untuk menjelaskan dan menganalisis implementasi kebijakan hutan pendidikan dengan model implementasi sebagai proses administrasi dan politik dari Grindle (1980) studi pada hutan pendidikan UB Forest. Hasil penelitian ini menunjukkan bahwa implementasi kebijakan hutan pendidikan di UB forest masih sulit dan berpotensi besar untuk mengalami kegagalan. Kegagalan tersebut dikarenakan belum tercapainya tujuan UB Forest, program kegiatan yang berlum terlaksana sesuai desain, dan belum berdampak bagi semua kalangan. Hal tersebut dipengaruhi dari berbagai aspek baik dari isi kebijakan, yang meliputi a) kepentingan yang dipengaruhi; b) tipe manfaat; c) derajat perubahan; d) letak pengambilan keputusan; e) pelaksana program, dan f) sumberdaya yang digunakan, dan lingkungan implementasi, yang meliputi tiga aspek yaitu: a) kekuasaan, kepentingan, dan strategi dari aktor yang terlibat; b) karakteristik lembaga dan rezim yang berkuasa; c) kepatuhan dan responsibilitas.

2021 FIA UB. All rights reserved.

\section{Pendahuluan}

Undang-Undang Nomor 41 Tahun 1999 tentang kehutanan menjelaskan bahwa hutan merupakan suatu kesatuan ekosistem yang berupa hamparan lahan berisi sumber daya alam hayati yang didominasi pepohonan dalam persekutuan alam lingkungannya, yang satu dengan yang lainnya tidak dapat dipisahkan. Berdasarkan fungsinya, hutan di Indonesia dikelompokkan menjadi

* Corresponding author. Tel.: +62-823-3106-6371; e-mail: annafiulaizi@ gmail.com 
hutan yang berfungsi konservasi, hutan yang berfungsi lindung, dan hutan yang berfungsi produksi.

Dijelaskan pula dalam UU Nomor 41 Tahun 1999 bahwa kehutanan yang mengatur Kawasan Hutan Dengan Tujuan Khusus yang selanjutnya disebut KHDTK menjelaskan bahwa pemerintah dapat menetapkan kawasan hutan tertentu untuk tujuan khusus. Penetapan KHDTK diperlukan untuk kepentingan umum seperti penelitian dan pengembangan, pendidikan dan latihan, serta religi dan budaya yang telah diatur dalam UU No 41 Tahun 1999 tentang kehutanan. Disamping itu perlu diperhatikan bahwa pengelolaan KHDTK tidak mengubah fungsi pokok daripada kawasan hutan itu sendiri.

Peraturan Menteri (Permen) Lingkungan Hidup dan Kehutanan No P.15/MENLHK/SETJEN/Kum.1/5/2018 tentang Kawasan Hutan Dengan Tujuan Khusus; menjelaskan bahwa pengelolaan KHDTK adalah sistem pengelolaan hutan lestari, komprehensif, mandiri, dan terpadu yang melibatkan berbagai disiplin keilmuan untuk tujuan penelitian dan pengembangan kehutanan, pendidikan dan pelatihan kehutanan, serta religi. KHDTK diklat kehutanan adalah kawasan hutan yang ditetapkan oleh menteri untuk pendidikan dan pelatihan kehutanan yang terampil, profesional, berdedikasi, jujur, serta amanah dan berakhlak mulia, yang mampu menguasai serta mampu memanfaatkan dan mengembangkan ilmu pengetahuan dan teknologi dalam pengurusan hutan.

Hutan pendidikan merupakan salah satu Kawasan Hutan Dengan Tujuan Khusus yang menjadi kawasan bagi masyarakat luas, khususnya bagi pelajar, mahasiswa, dan peneliti untuk mempelajari lebih dalam mengenai hutan dan seluruh komponen ekosistem alam yang terdapat didalamnya. Selain itu, KHDTK yang dikelola oleh perguruan tinggi berperan penting sebagai media pembelajaran untuk berlangsungnya riset-riset dan inovasi khususnya pada fokus kehutanan yang menjadi sumber atau bahan pengambilan keputusan pemerintah berbasis riset.

UB Forest sebagai salah satu hutan pendidikan dan pelatihan di Indonesia, sebagian luas lahannya dikembangkan dengan sistem agroforestri. Dalam sistem agroforestri lahan hutan terdapat berbagai macam jenis tanaman yang berdampingan khususnya tanaman tahunan dan tanaman musiman.

Lundgren \& Raintree (1982) mendefinisikan agroforestri menjadi sebuah istilah yang kolektif untuk sistem-sistem dan teknologi-teknologi penggunaan lahan, yang secara terencana dilaksanakan pada satu unit lahan dengan mengkombinasikan tumbuhan berkayu (pohon, perdu, palem, bambu, dan sebagainya) dengan tanaman pertanian dan/ atau hewan (ternak) dan/ atau ikan, yang dilakukan pada waktu yang bersamaan atau bergiliran, sehingga terbentuk interaksi ekologis dan ekonomis antar berbagai komponen yang ada (Widiyanto dkk, 2003).

Banyaknya hutan pendidikan yang dikelola oleh universitas dan tersebar dipenjuru Indonesia tidak terlepas dari masalah-masalah yang sering muncul, terutama, yaitu mengenai masalah bahwa belum terdapat kebijakan khusus yang secara sah mengatur tentang hutan pendidikan dan digunakan dalam pengelolaannya. Dibeberapa kasus terdapat tumpang tindih beberapa kebijakan, sehingga implementasi yang dilakukan tidak sesuai atau tidak dapat mencapai tujuan yang telah ditetapkan.

Dikutip dalam Grindle (1980) yang menjelaskan bahwa keberhasilan implementasi kebijakan publik dipengaruhi oleh dua aspek yang fundamental, pertama adalah isi kebijakan (content of policy) dan kedua adalah lingkungan implementasi (context of implementasi).

Implementasi kebijakan hutan pendidikan di UB Forest memiliki banyak kegiatan yang melibatkan para akademisi maupun peneliti yang memiliki tujuan dalam melaksanakan penelitian, praktikum, dan pengabdian. Implementasinya sendiri terdapat perbedaan pengelolaan dan tujuan-tujuan pada kawasan hutan, jika sebelumnya kawasan hutan tersebut dikelola oleh pihak perhutani dan akhirnya dipindah pengelolaan menjadi hutan pendidikan UB Forest yang berada dibawah naungan lembaga pendidikan tinggi Universitas Brawijaya. Pergantian pengelolaan tersebut memunculkan dampak bagi masyarakat sekitar hutan yang sudah sejak lama menggantungkan perekonomian dari hasil hutan tersebut.

Ketika dikelola oleh pihak perhutani, petani yang tinggal di sekitar hutan (magersaren) maupun petani yang tidak tinggal di sekitar hutan (pesanggem) menggantungkan perekonomian dengan memanfaatkan hasil utama hutan, yaitu pohon pinus. Pengelolaan dengan perhutani saat itu dimana para petani memanfaatkan getah pinus dan kayu pinus dengan sistem tebang tanam pada saat itu yang kemudian hasilnya disetorkan kepada pihak perhutani.

Perubah pengelolaan kepada Universitas Brawijaya/ UB Forest manajemen dan menjadi hutan pendidikan, petani magersaren maupun pesanggem masih tetap mengolah lahan UB Forest dengan hasil utama hutan yaitu kopi, dan tidak lagi memberlakukan tebang tanam maupun getah pinus karena untuk kelestarian hutan dimasa yang akan datang. Perubahan pengelolaan memerlukan waktu yang tidak singkat agar dapat diterima oleh semua kalangan yang terlibat terutama petani yang mengolah lahan hutan dan masyarakat yang tinggal dikawasan hutan UB Forest.

Pelaksanaan kebijakan yang melibatkan beberapa stakeholder dan diikuti dengan kepentingan-kepentingan yang mempengaruhi kebijakan itu sendiri, sehingga tanggung jawab akan pengelolaan hutan pendidikan juga harus melibatkan keseluruhan stakeholder, dari 
banyaknya kepentingan-kepentingan tersebut nantinya akan mampu mensejahterakan masyarakat yang tinggal dikawasan hutan maupun masyarakat yang tidak tinggal dikawasan hutan atau sebaliknya yang menyebabkan kesejahteraan masyarakat menurun karena melibatkan banyak kepentingan dan perbedaan kepentingan.

Perbedaan kepentingan dan aspek yang lain yang melibatkan UB Forest Manajemen dan para petani yang menggantungkan perekonomiannya dengan mengelola lahan hutan UB Forest sebagai hutan pendidikan akan diketahui sulit atau tidak dan berhasil atau berpotensi mengalami kegagalan. Dengan latar belakang yang telah dijelaskan, maka akan dibahas lebih dalam lagi dalam tulisan ini yang berjudul "Implementasi Kebijakan Hutan Pendidikan (Studi pada UB Forest, Dusun Sumbersari, Desa Tawangargo, Malang)".

\section{Teori}

\subsection{Kebijakan Publik}

\subsubsection{Definisi Kebijakan Publik}

Wahab (2011) dalam bukunya analisis kebijakan menjelaskan bahwa studi kebijakan publik ialah studi yang bermaksud mendeskripsikan, menganalisis, dan menjelaskan secara cermat berbagai sebab dan akibat dari tindakan-tindakan pemerintah diberbagai bidang kehidupan. Seperti yang dikutip dalam Wahab (2017) secara tepat dituliskan oleh Dye (1978) bahwa studi kebijakan publik mencangkup upaya untuk mendeskripsikan isi kebijakan publik, penilaian mengenai dampak dari kekuatan-kekuatan yang berasal dari lingkungan terhadap isi kebijakan publik, analisis mengenai akibat dari berbagai pengaturan kelembagaan dan proses-proses politik terhadap kebijakan publik, penelitian mendalam mengenai akibat-akibat dari berbagai kebijakan publik terhadap sistem politik, dan evaluasi dampak kebijakan publik pada masyarakat, baik berupa dampak yang diharapkan (yang direncanakan) maupun dampak yang tidak diharapkan.

\subsubsection{Proses Kebijakan Publik}

Nugroho (2017) menyebutkan bahwa dalam proses kebijakan publik dapat digeneralisir dengan beberapa tahapan, yaitu sebagai berikut:

a) Tahap 1, yaitu masalah kebijakan, terdapat isu atau masalah kebijakan publik, disebut isu apabila masalah bersifat strategis yakni bersifat mendasar, menyangkut kepentingan umum bahkan keselamatan bersama dan biasanya berjangka panjang. Isu seperti ini dapat diangkat sebagai agenda politik untuk segera diselesaikan;

b) Tahap 2, yaitu perumusan kebijakan, isu-isu tersebut kemudian menggerakkan pemerintah utuk merumuskan kebijakan publik dalam rangka menyelesaikan masalah tersebut. Rumusan kebijakan publik tersebut akan menjadi hukum bagi seluruh negara dan warganya termasuk pimpinan negara;

c) Tahap 3, yaitu implementasi kebijakan, setelah dirumuskan ditahap kedua selanjutnya kebijakan publik ini dilaksanakan baik oleh pemerintah maupun bersama-sama dengan masyarakat, dan

d) Tahap 4, yaitu evaluasi kebijakan, pada tahap ke empat. Didalam proses perumusan, pelaksanaan, dan pasca pelaksanaan diperlukan tindakan evaluasi sebagai sebuah siklus baru bagi pelaksana sebagai penilai apakah kebijakan tersebut sudah dirumuskan dengan baik dan benar.

\subsection{Implementasi Kebijakan Publik}

\subsubsection{Definisi Implementasi Kebijakan}

Studi tentang implementasi kebijakan dapat ditemukan dalam berbagai disiplin ilmu administrasi publik, teori organisasi, penelitian manajemen publik, dan studi ilmu politik (Schofield \& Sausman, 2004) dalam (Pulzl \&Treib, 2006). Studi implementasi kebijakan muncul pada Tahun 1970-an di Amerika Serikat sebagai reaksi atas keprihatinan kegagalan efekivitas program reformasi luas. Implementasi kebijakan pada prinsipnya merupakan sebuah cara agar suatu kebijakan yang dibentuk dapat mencapai tujuannya. Tidak lebih dan tidak kurang.

Mengutip Sabatier \& Mazmanian (1979) menyatakan bahwa, implementasi adalah memahami apa yang senyatanya terjadi sesudah suatu program dinyatakan berlaku atau dirumuskan merupakan fokus perhatian implementasi kebijaksanaan, yakni kejadiankejadian dan kegiatan-kegiatan yang timbul sesudah disahkannya pedoman-pedoman kebijaksanaan negara yang mencangkup baik usaha-usaha untuk mengadministrasikannya maupun untuk menimbulkan akibat/ dampak nyata pada masyarakat atau kejadiankejadian.

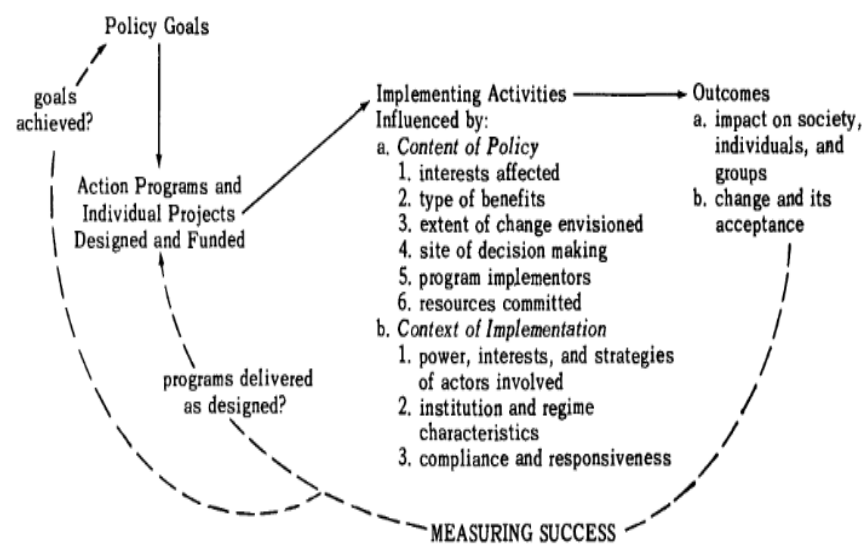

Gambar 1 Implementasi Sebagai Proses Politik dan Administrasi

Sumber: Grindle, 1980 
Grindle memperkenalkan model implementasi sebagai proses politik dan administrasi. Model tersebut menggambarkan proses pengambilan keputusan yang dilakukan oleh beragam aktor, dimana hasil akhirnya yang akan ditentukan oleh tujuan dan desain program yang telah dicapai maupun melalui interaksi para pembuat keputusan dalam konteks politik administratif. Proses politik dapat terlihat melalui proses pengambilan keputusan yang didalamnya banyak melibatkan berbagai aktor kebijakan, sedangkan proses administrasi dapat diketahui melalui proses umum mengenai aksi dari pelaksanan program.

Keberhasilan suatu implementasi kebijakan publik dikutip dalam Grindle (1980) yang ditentukan oleh tingkat implementability kebijakan itu sendiri, yang terdiri atas isi kebijakan (Content of Policy) dan Lingkungan kebijakan (Context of Implementation). Isi kebijakan (Context of Policy) itu sendiri terdiri dari sebagai berikut:

- Interest Affected (Kepentingan-kepentingan yang mempengaruhi).

Interest affected berkaitan dengan kepentingan yang mempengaruhi suatu implementasi kebijakan.

- Type Of benefit (Tipe Manfaat)

Tipe manfaat dimaksudkan untuk menunjukkan atau menjelaskan bahwa dalam suatu kebijakan harus terdapat beberapa jenis manfaat yang menunjukkan dampak positif yang dihasilkan oleh pengimplementasian kebijakan yang hendak dilaksanakan.

- Extend of Change Envision (Derajat Perubahan yang Ingin Dicapai)

Pada setiap kebijakan yang ditetapkan memiliki target yang hendak dan ingin dicapai.

- Site of Decision Making (Letak Pengambilan Keputusan)

Pengambilan keputussan dalam suatu kebijakan memegang peranan penting dalam pelaksanaan suatu kebijakan.

- Program implementer (Pelaksana Program)

Mengimplementasikan suatu kebijakan atau program harus didukung dengan adanya pelaksana kebijakan yang kompeten dan kapabel untuk keberhasilan suatu kebijakan.

- Resource committed (Sumber - sumber daya yang digunakan). Apakah sebuah program didukung oleh sumber daya yang memadai. Pelaksanaan kebijakan harus didukung oleh sumber daya yang mendukung yang ditujukan agar dalam pelaksanaannya berjalan dengan baik.

Context of implementation dari model implementasi Grindle (1980) mencangkup tiga hal, yaitu sebagai berikut:

- Power, Interest, and Strategy of Actor Involved (kekuasaan, kepentingan-kepentingan, dan strategi dari aktor yang terlibat) kebijakan pada pelaksanaannya perlu dipertimbangkan aspekaspek kekuasaan, kepentingan, serta stategi yang digunakan oleh pada aktor yang terlibat guna memperlancar jalannya pelaksanaan suatu implementasi kebijakan;

- Institution and Regime Characteristic (Karakteristik lembaga rezim yang sedang berkuasa). Lingkungan dari suatu kebijakan diimplementasikan akan mempengaruhi berhasil tidaknya kebijakan tersebut, maka pada bagian ini ingin dijelaskan karakteristik dari suatu lembaga yang akan turut memepngaruhi suatu kebijakan; dan

- Compliance and Responsiveness (Tingkat kepatuhan dan Adanya Respon dari Pelaksana). Salah satu aspek penting pada proses pelaksanaan suatu kebijakan, yaitu terkait kepatuhan dan respon dari para pelaksana kebijakan itu sendiri. Compliance and Responsivness menjelaskan sejauhmana kepatuhan dan respon dari pelaksana dalam menanggapi suatu kebijakan.

\subsection{Pembangunan Berkelanjutan}

Konsep pembangunan berkelanjutan dirumuskan pada kurun waktu Tahun 2017-an, hal tersebut sebagai tanggapan akan strategi pembangunan sebelumnya yang hanya terfokus pada tujuan pertumbuhan ekonomi yang tinggi. Strategi pembangunan tersebut telah memberikan bukti akan adanya degradasi kapasitas produksi maupun kualitas lingkungan hidup. Kenyataan yang terjadi bahwa pembangunan yang ditempuh selama ini telah menimbulkan dampak negatif terhadap lingkungan, pada akhirnya hal tersebut dapat mengancam keberlangsungan pembangunan itu sendiri (Zaini \& Darmawanto, 2015).

Menurut Sugandi, dkk (2007) dalam Zaini \& Darmawanto (2015), dinyatakan bahwa model pembangunan berkelanjutan didasarkan atas tiga pilar utama yang ketiganya saling berkaitan, yaitu pertama, society yang berkaitan dengan peran masyarakat, responsibility (tanggung jawab) interaksi sosial, keperilakuan masyarakat dan kondisi sosial masyarakat yang ada disuatu wilayah. Kedua, yaitu environment, berkaitan dengan lingkungan alam, termasuk lingkungan fisik serta adanya seperangkat kelembagaan sebagai hasil buatan manusia dalam rangka pemanfaatannya. Ketiga adalah economy, yaitu kesejahteraan ekonomi masayarakat dan pemanfaatan lingkungan alam untuk memenuhi kebutuhan masyarakat termasuk dalam rangka memperoleh keuntungan.

Ketiga pilar tersebut dalam pembangunan berkelanjutan saling berkaitan satu sama lain. Apabila dalam pelaksanaannya ketiganya dilakukan secara seimbang dan tetap mengaitkan satu sama lain, maka 
sumber daya saat ini akan dapat dinikmati untuk generasi yang selanjutnya.

\subsection{Kawasan Hutan dengan Tujuan Khusus}

Penetapan suatu Kawasan Hutan Dengan Tujuan Khusus selain pemanfaatan aspek lingkungan juga dapat dimanfaatkan secara optimal bagi kepentingan ekonomi dan sosial, akan tetapi dalam pemanfaatannya harus diatur menurut luas dan kaidah pelestarian lingkungan (Bakar dalam Luginia, dkk, 2016).

Undang-Undang Nomor 41 Tahun 1999 tentang kehutanan memuat tentang terbentuknya Kawasan Hutan Dengan Tujuan Khusus (KHDTK) yang menyebutkan bahwa pemerintah dapat menetapkan kawasan hutan tertentu untuk tujuan khusus. Penerapan KHDTK diperlukan untuk kepentingan umum seperti penelitian dan pengembangan, pendidikan dan latihan, serta religi dan budaya yang diatur dalam pasal 8 UU No. 41 Tahun 1999. KHDTK yang dijelaskan tersebut tidak mengubah fungsi pokok Kawasan hutan. Tujuan dari pengelolaan KHDTK bertujuan untuk bisa menghasilkan hutan yang memenuhi persyaratan dijadikan sebagai laboratorium alam untuk menunjang kegiatan penelitian.

\subsection{Agroforestri}

Pahamanan secara sederhana, agroforestri berarti menanam pepohonan pada lahan pertaian, dan point pentingnya adalah petani atau masyarakat sebagai elemen pokok (subyek). Dengan demikian kajian agroforestri tidak hanya terfokus pada masalah teknik dan biofisik saja, tetapi juga masalah sosial, ekonomi, dan budaya yang selalu berubah dari waktu ke waktu (Widiyanto dkk, 2003).

Sistem agroforestri memiliki interaksi ekologi, sosial, maupun ekonomi di antara komponen-komponen yang ada didalamnya (Nair, 1993). Pengembangan agroforestri, mengutip Reintree (1983) meliputi tiga aspek, yaitu: a) Meningkatkan produktivitas sistem agroforestri; b) Mengusahakan keberlanjutan sistem agroforestri yang sudah ada; dan c) Penyebarluasan sistem agrforestri sebagai alternatif atau pilihan dalam penggunaan lahan yang memberikan tawaran lebih baik dalam berbagai aspek (adoptability) (Widiyanto dkk, 2003).

Pengelolaan lahan pertanian dengan sistem agroforestri terbilang cukup kompleks karena dalam prosesnya mengabungkan antara bidang kajian ilmu kehutanan dengan pertanian dan juga peternakan, serta memadukan kegiatan-kegitan pada kehutanan dengan pembangunan pedesaan untuk dalam menciptakan keselarasan antara intensifikasi pertanian dan pelestarian hutan.

\section{Metode Penelitian}

Penelitian ini merupakan penelitian kualitatif dengan studi kasus. penelitian kualitatif merupakan metode-metode yang cenderung dilakukan untuk mencari dan memahami makna dari masalah sosial dan/ atau kemanusiaan. Penelitian kualitatif adalah penelitian yang bertujuan memahami fenomena yang dialami oleh subjek penelitian pada kondisi objek yang alamiah (Moleong, 2011, h. 6).

Metode penelitian dengan studi kasus digunakan peneliti karena berusaha untuk mengetahui bagaimana implementasi kebijakan hutan pendidikan di UB Forest sebelum dikelola dibawah Universitas Brawijaya dan setelah dikelola oleh UB Forest dengan beberapa aspek dari Grindle, karena sebelumnya pengelola utama hutan adalah perhutani.

Peneliti mengumpulkan data dan mendeskripsikan serta menganalisis bagaimana implementasi kebijakan hutan pendidikan di UB Forest, program aksi atau proyek kegiatan yang nantinya akan mengetahui hasil akhir implementasi kebijakan tersebut.

Penelitian ini menggunakan teknik analisis model logis, Penggunaan model logis dalam teknik analisis ini terdiri dari mencocokkan secara empiris kejadiankejadian yang diobservasi terhadap kejadian-kejadian yang akan diprediksi secara teoritis. Dalam penelitian menggunakan model implementasi Grindle, model logis menjelaskan aspek-aspek dan sub aspek dalam model implementasi Grindle. Dimulai dengan policy goals (tujuan kebijakan) dari UB Forest yang kemudian dilanjutkan dengan program aksi dan proyek-proyek yang telah dirancang dan didanai dalam pelaksanaan program hutan pendidikan UB Forest, hingga pada hasil akhir yang terlihat atau dirasakan.

Aspek-aspek atau dalam model Grindle disebut sebagai variabel yang mempengaruhi atas proses kebijakan, yaitu isi kebijakan (content of policy) dan lingkungan kebijakan (context of implementation) (Grindle, 1980). Dijelaskan pula secara model logis hasil akhir/ outcome dari implementasi kebijakan hutan pendidikan di UB Forest, yaitu pengaruhnya terhadap sosial, individu, dan kelompok-kelompok disekitar kawasan hutan dan perubahan serta penerimaan dari implementasi kebijakan hutan pendidikan di UB Forest.

\section{Hasil Penelitian dan Pembahasan}

\subsection{Implementasi Kebijakan Hutan Pendidikan di UB Forest}

\subsubsection{Tujuan Implementasi Kebijakan Hutan Pendidikan di UB Forest}


Tujuan dari implementasi kebijakan hutan pendidikan di UB Forest disebutkan dalam masterplan UB Forest 2015, yaitu sesuai dengan pelaksanaan Tridharma perguruan tinggi. UU Nomor 12 Tahun 2012 tentang pendidikan tinggi menjelaskan bahwa Tridharma perguruan tinggi adalah kewajiban perguruan tinggi untuk menyelenggarakan pendidikan, penelitian, dan pengabdian kepada masyarakat.

Dijelaskan pula pada peraturan Menteri lingkungan hidup Nomor P.15/MENLHK/SETJEN/KUM.1/5/2018 tentang KHDTK yang menyebutkan bahwa KHDTK yang ditetapkan oleh menteri untuk pendidikan dan pelatihan kehutanan yang ditujukan untuk mendorong peningkatan kualitas sumber daya manusia kehutanan yang terampil, professional, berdedikasi, jujur serta amanah dan berakhlak mulia, yang mampu menguasai serta mampu memanfaatkan dan mengembangkan illmu pengetahuan dan teknologi dalam pengurusan hutan.

Sebelum perubahan pengelolaan, UB Forest memiliki fungsi sebagai hutan produksi yang dikelola oleh perhutani dan bekerjasama dengan masyarakat petani sekitar hutan. Pada saat ini pengelolaan oleh UB Forest manajemen bertambah fungsi sebagai hutan pendidikan dan tetap memiliki fungsi sebagai hutan produksi aktif. Sehingga sekarang ini UB Forest memiliki fungsi ganda sebagai hutan pendidikan dan sebagai hutan produksi aktif.

Tujuan dari UB Forest sebagai hutan pendidikan dijabarkan menjadi beberapa poin sebagai berikut, yaitu sebagai berikut:

a) Sebagai laboratorium lapangan, dan menjadi tempat observasi bagi mahasiswa dan peneliti;

b) Sebagai pusat penelitian serta membangun sumber belajar yang bertujuan untuk meningkatkan sumber daya manusia melalui program pendidikan di UB Forest dan terkait dengan interdisiplin;

c) Sebagai bentuk optimalisasi dan pemanfaatan hutan secara berkelanjutan untuk meningkatkan kemitraan kepada masyarakat dan instansi lain dan peningkatan mutu pengelolaan perguruan tinggi; dan

d) Sebagai tempat untuk pendidikan dan pelatihan multi disiplin berbasis hutan, dan sebagai tempat percontohan kegiatan hutan lindung dan konservasi alam.

Hodwood \& Gunn (1978) (dalam Sulastri, 2009) menyebutkan pemahaman yang mendalam dan kesepakatan terhadap tujuan. Hal itu mengharuskan adanya pemahaman yang menyeluruh tentang kesepakatan terhadap tujuan atau sasaran yang akan dicapai. Tujuan tersebut haruslah dirumuskan dengan jelas, spesifik, dan lebih baik lagi apabila dapat dikualifikasikan, dipahami, serta disepakati oleh seluruh pihak yang terlibat, bersifat saling melengkapi dan mendukung, serta mampu berperan sebagai pedoman dalam implementasi, sehingga pelaksanaan program dapat dimonitor dengan baik (Sulastri, 2009).

Perlu diperhatikan lagi bahwa hutan pendidikan UB Forest berdampingan dengan masyarakat yang sudah tinggal disana jauh sebelum hutan tersebut dikelola oleh UB Forest Manajemen. Sesuai dengan UU No 41 Tahun 1999 tentang Kehutanan; bahwa pengelolaan Kawasan Hutan Dengan Tujuan Khusus perlu memperhatikan kesejahteraan masyarakat disekitar kawasan hutan. Sehingga penting dalam pengelolaan UB Forest juga memperhatikan kesejahteraan masyarakat.

\subsubsection{Program Aksi atau Kegiatan Hutan Pendidikan UB Forest}

Grindle (1980) mengatakan bahwa "the general process of implementation thus can begin only when general goals and objectives have been specified, when action programs have been designed and when funds have been allocated for the pursuit of the goals". Tujuan yang telah ditetapkan akan dapat tercapai dengan program aksi atau kegiatan yang sebagai bentuk implementasi kebijakan.

Konsep kegiatan untuk mencapai tujuan pelaksanaan hutan pendidikan disebutkan pada masterplan UB Forest 2015, yaitu riset, pendidikan, dan wisata (Gambar 2):

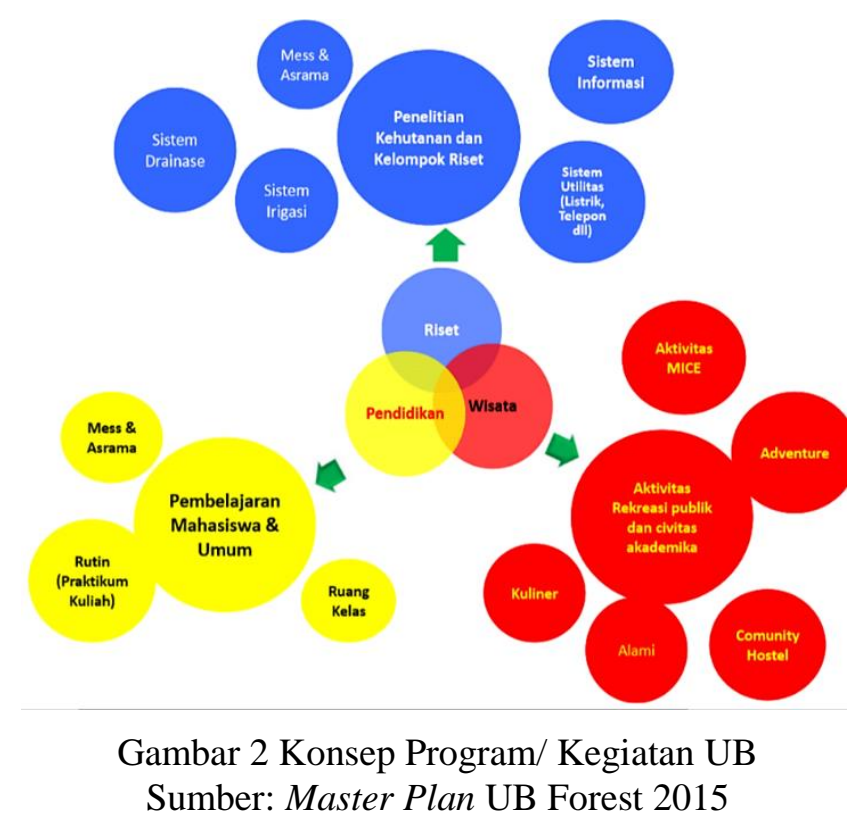

Kegiatan implementasi kebijakan hutan pendidikan di UB Forest belum dilaksanakan secara keseluruhan. Untuk kegiatan riset sampai saat ini sudah berjalan baik karena memang dalam pengembangan hutan sudah dilakukan dengan sistem agroforestri, yang menarik minat peneliti danmahasiswa untuk melakukan penelitian, dengan banyaknya mahasiswa dan peneliti yang datang untuk melakukan riset dari berbagai disiplin ilmu. 
Pada kegiatan pendidikan yang melibatkan pembelajaran mahasiswa dan umum belum terlaksana sesuai dengan tujuan, karena hanya melibatkan mahasiswa khususnya pada jurusan pertanian di Universitas Brawijaya, untuk mahasiswa yang fakultas lain dan masyarakat umum belum mengetahui tentang eksistensi UB Forest sebagai hutan pendidikan. Dan yang terakhir adalah sebagai kegiatan wisata, samapi saat ini belum ada tanda-tanda akan perkembangan kearah wisata yang sudah gambarkan dan dijelaskan dalam konsep kegiatan.

Program aksi/ kegiatan wisata belum secara nyata direalisasikan secara maksimal, dapat dikatakan masyarakat petani hanya mengandalkan perekonomian sebagai petani kopi dan belum bisa dikatakan bahwa dengan pekerjaan tersebut petani di kawasan UB Forest mengalami peningkatan dari segi ekonomi. Sedangkan untuk riset dan pendidikan sampai saat ini sudah berjalan bagi peneliti maupun mahasiswa, dengan kemudahan akses yang diberikan UB Manejemen dan banyaknya mahasiswa/peneliti yang datang untuk melakukan riset dan pendidikan di UB Forest akan tetapi hanya berlaku untuk peneliti yang sudah mengetahui akan kondisi exsisting UB Forest, dan mahasiswa yang dominan pada mahasiswa fakultas pertanian Universitas Brawijaya, belum mencangkup pada mahasiswa pada umumnya.

\subsubsection{Desain Program Aksi atau Kegiatan Hutan Pendidikan UB Forest}

Pertama, sebagai kegiatan riset yang melibatkan penelitian kehutanan dan kelompok riset yaitu riset desain pengelolaan lahan berbasis DAS mikro dan tekonologi konservasi tanah dan air yang tujuannya untuk mencari dan mengembangkan teknologi konservasi dengan tetap menjaga environmental sustainability dan penelitian tentang pertanian berkelanjutan sebagai hutan pendidikan UB Forest yang menjamin keberlangsungan lingkungan, sosial, dan ekonomi antara kedua belah pihak baik masyarakat maupun pengelola.

Kedua, kegiatan pembelajaran, kegiatan ini di desain untuk mahasiswa dan umum. Dimaksudkan agar semua masyakarat luas bisa mempelajari hutan dan keanekaragamannya melalui kegiatan ini. Beberapa fasilitas diberikan dalam desain kegiatan ini adalah mess dan asrama, ruang kelas yang memadai, dan rutin adanya praktikum kuliah.

Ketiga, kegiatan UB Forest untuk wisata yang melibatkan aktivitas rekreasi publik dan civitas akademika dengan fasilitas yang diberikan aktivitas MICE, adventure, community hostel, alami, dan kuliner. Sebenarnya untuk tujuan wisata di UB Forest masih belum terlaksana, karena ini masih sekedar konsep dan belum terealisasikan, karena dikelola oleh UB Forest manajemen, kawasan hutan ini merupakan hutan lindung dan hutan produksi yang dikelola oleh perhutani.
Terkait fungsi hutan produksi di UB Forest, lahan hutan dikelola oleh petani pesanggem dan magersaren dengan memproduksi kopi yang ditanam di antara tegakan. Dengan kebijakan dimana seluruh hasil produksi kopi nantinya akan dibeli oleh UB Forest.

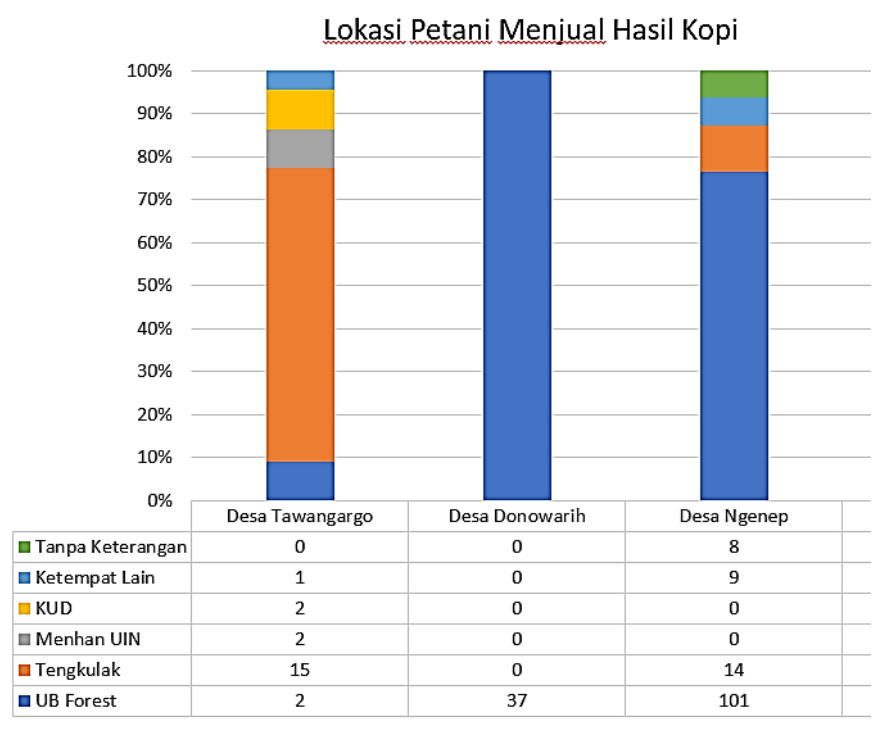

Gambar 3 Lokasi Penjualan Kopi UB Forest

Sumber: Hasil analisis, 2020

Pada desain program terkait pengelolaan hasil kopi di UB Forest, masih tidak berjalan dengan baik, karena adanya rasa kurang percaya petani terhadap UB Forest dan kurangnya komunikasi dari UB Forest kepada petani. Sehingga sebagian petani menjual hasil kopi pada tengkulak. Ketidaksesuaian implementasi kebijakan dengan desain yang telah ditetapkan menyebabkan implementasi kebijakan tidak berhasil atau gagal.

\subsubsection{Dampak dan Perubahan dan Penerimaan Implementasi Hutan Pendidikan UB Forest}

Jika dibandingkan saat dikelola oleh perhutani dan dikelola oleh UB terdapat beberapa perbedaan seperti yang dahulunya hutan produksi namun saat ini menjadi hutan pendidikan. Pengelolaan UB Forest yang mengizinkan untuk menanam kopi dengan syarat bagi hasil dapat membantu petani sebagai mata pencaharian.

Walaupun petani telah diizinkan untuk menanam kopi, petani masih merasa bahwa pendapatan yang didapat belum maksimal atau belum merasakan perekonomian yang lebih baik. Hal tersebut karena petani tidak dapat sepenuhnya mendapatkan hasil jual seutuhnya. Menurut petani menjual hasil kopi lebih untung saat dijual langsung ke tengkulak daripada dijual ke UB Forest.

Grindle mengatakan bahwa implementasi memiliki tugas "to establish a link that allows the goals of public policies to be realized as outcomes of governmental activity" (Grindle, 1980). Implementasi adalah semacam jembatan yang menghubungkan antara tujuan kebijakan publik dengan realitas yang diinginkan. Untuk mengukur 
berhasil tidaknya suatu kebijakan adalah dilihat dari apakah tujuan kebijakan tersebut sudah tercapai atau belum

Dari hasil survey menggunakan beberapa gambar pilihan, mereka menggambarkan kondisi UB Forest saat ini seperti anak dengan wajah sedih pada Gambar 4 Sebelah kiri, dan menginginkan kondisi UB Forest dimasa yang akan datang seperti pada Gambar 4 sebelah kanan, gambar tersebut dipilih oleh beberapa petani di Dusun Sumbersari dan Dusun Sumberwangi, dan dapat dideskripsikan bahwa kondisi UB Forest saat ini masih jauh dari harapan dan keinginan untuk petani dimana pengelolaan UB Forest kedepannya bisa lebih mensejahterakan petani kopi dan masyarakat yang tinggal di kawasan UB Forest.
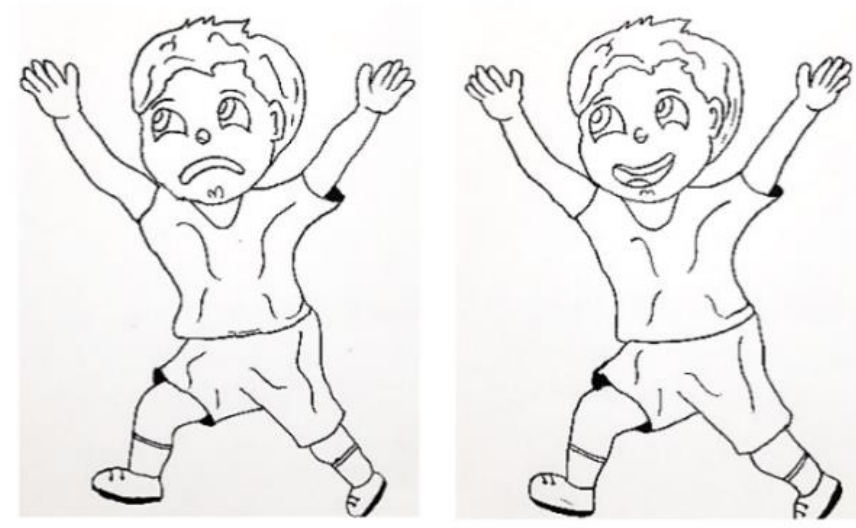

Gambar 4 Gambaran UB Forest saat ini (kiri),

Gambaran Harapan Untuk UB Forest kedepannya (kanan)

Sumber: Hasil analisis, 2020

Dampak nyata akan implementasi kebijakan hutan pendidikan belum menjangkau berbagai kalangan, hanya untuk UB Forest sendiri selaku pengelola dan pemilik lahan dikawasan hutan, sedangkan petani terutama petani magersaren yang bekerja pada lahan UB Forest sebagai petani kopi, dan peneliti atau mahasiswa belum merasakan dampak pengelolaan lahan pada UB Forest.

\subsection{Isi Kebijakan dan Lingkungan Implementasi}

\subsubsection{Kepentingan yang Mempengaruhi}

Mengutip dari Pressman \& Wildavsky (1973), bahwa sebuah kebijakan yang berhubungan sebab-akibat tergantung pada mata rantai yang panjang, maka ia akan mudah sekali mengalami keretakan, sebab semakin panjang mata rantai kausalitas, semakin besar hubungan timbal balik diantara mata rantai penghubungnnya dan implementasinya semakin kompleks

Kebijakan hutan pendidikan pada UB Forest yang mempengaruhi banyak kepentingan, antara lain yaitu sebagai berikut:

a) Perhutani $\mathrm{KPH}$; adanya perubahan pengelolaan dari tangan perhutani ke UB Forest, maka kepentingan perhutani selaku pengelola utama hutan produksi di Dusun Sumbersari, Desa Tawangargo ini tidak berlaku lagi, sehingga pengelolaan yang berhubungan dengan luas hutan atau daerah yang dikelola perhutani menjadi berkurang;

b) UB Forest Manajemen; kepentingan UB Forest manajemen memiliki lahan untuk penelitian bagi mahasiswa Universitas Brawijaya sebagai laboratorium lapang, mengelola hutan pendidikan dan hutan produksi, dan kepentingan pelaksanaan tridharma perguruan tinggi;

c) Petani pesanggem dan petani magersaren; mengolah lahan untuk kepentingan meningkatkan taraf hidup dari segi perekonomian;

d) Masyarakat dikawasan hutan; mempertahankan adat dan budaya mereka, dan bertanggung jawab atas keberlangsungan hidup mereka dengan tetap bisa beraktifitas di tempat tinggal mereka;

e) KUD; secara tidak langsung berkepentingan berkoordinasi dengan UB Forest Manajemen terkait pengelolaan hutan dan membantu para petani dalam mengelola hasil hutan; dan

f) Mahasiswa dan peneliti; memiliki lokasi untuk melaksanakan penelitian riset dan pendidikan dan menambah wawasan tentang kehutanan.

Implementasi kebijakan hutan pendidikan pada UB Forest melibatkan banyak kepentingan dan tiap-tiap kepentingan memiliki perbedaan. Oleh karena itu pelaksanaan kebijakan hutan pendidikan di UB Forest sulit dilaksanakan, karena banyaknya kepentingan yang dipengaruhi.

\subsubsection{Jenis Manfaat}

Implementasi kebijakan hutan pendidikan di UB Forest saat ini lebih untuk laboratorium lapang yang dimanfaatkan oleh peneliti dan mahasiswa sebagai research centre. Selain itu manfaat lainnya kembali lagi kehutan dengan sistem agroforestri yang memanfaatkan sela-sela tegakan untuk tanaman kopi dan tetap menjaga tegakan, yaitu pohon pinus dan mahoni sebagai naungan pohon kopi untuk pengelolaan hutan produksi, selain itu juga untuk menjaga hutan tetap lestari.

UB Forest termasuk kawasan hutan yang didalamnya terdapat tempat tinggal masyarakat, sehingga sudah wajib UB Forest Manajemen juga memperhitungkan manfaat yang harus dirasakan oleh masyarakat sekitar karena adanya perpindahan pengelolaan dari perhutani menjadi UB Manajemen.

Implementasi sebuah kebijakan harus berupaya untuk menunjukkan atau menjelaskan bahwa suatu kebijakan harus menghasilkan beberapa jenis manfaat yang menunjukkan dampak positif. Semakin banyaknya stakeholder atau masyarakat yang merasakan manfaat dari kebijakan yang diimplementasikan, berarti kebijakan terlaksana dengan baik (Grindle, 1980). 
Para petani belum merasakan manfaat adanya pergantian pengelolaan dari perhutani kepada UB Forest Manajemen sebagai hutan pendidikan, terutama untuk masalah ekonomi. Pada saat ini sebagian masyarakat yang tinggal dikawasan hutan (magersaren) maupun untuk petani yang tidak tinggal dikawasan hutan (pesanggem) yang pekerjaan utamanya adalah sebagai petani dan mengandalkan perekonomian sebagai petani kopi.

Masyarakat sekitar atau petani yang bekerja mengolah lahan dikawasan UB Forest, belum mendapatkan manfaatnya terutama pada aspek ekonomi. Karena adanya penurunan pendapatan dari ketika dikelola oleh perhutani dan saat ini dikelola oleh UB Forest dan kurang lancaranya hubungan komunikasi diantara kedua stakeholder ini menjadi salah satu penyebab tidak maksimalnya manfaat yang dihasilkan dari implementasi kebijakan ini.

\subsubsection{Derajat Perubahan yang Ingin Dicapai}

Tingkat/ derajat perubahan yang diinginkan oleh UB Forest manajemen mengarah pada pengembangan kawasan hutan menjadi hutan pendidikan juga sebagai hutan produksi dengan membangun kerjasama dengan masyarakat melalui pengembangan pengelolaan kopi. Hal tersebut telah dikonsepkan dalam Master Plan UB Forest 2015. Sebagai kawasan hutan dengan sistem pengelolaan agroforestri maka UB Forest manajemen telah mengkonsep pengembangan UB Forest secara baik.

Derajat perubahan pada pengelolaan UB Forest mengakibatkan perubahan besar dan fundamental, termasuk juga pada perubahan pengelolaan sumber daya alamnya. Perubahan-perubahan tersebut meliputi perubahan tata guna lahan, perubahan aturan pada pengelolaan lahan hutan, adanya aturan zonasi lahan.

Sebagai kawasan hutan yang sebelumnya hanya sebagai hutan produksi dan saat ini dikelola oleh UB Forest sebagai hutan pendidikan perubahan tersebut menimbulkan konflik antar petani dan UB Manajemen. Karena beberapa perubahan mengenai penglolaan dan adanya zonasi lahan, sehingga petani dan masyarakat desa harus beradaptasi dengan perubahan-perubahan tersebut. namun hal tersebut menjadi permasalahan dalam pengelolaan UB Forest. Seperti yang ditampilkan pada Gambar 5.

Pada Gambar 5 tersebut, terlihat bahwa ketiga desa setuju bahwa pengelolaan SDA termasuk pada perubahan zonasi lahan, dan perubahan pengelolaan hutan merupakan permasalahan dalam pengelolaan UB Forest. Adanya perubahan tersebut yang dihanya menguntungkan pihak UB Forest saja, dan pihak petani merasakan kerugian karena menurunnya tingkat perekonomian mereka, sehingga mengakibatkan addnaya konflik internal, maka pelaksanaan kebijakan ini memiliki risiko gagal yang tinggi.

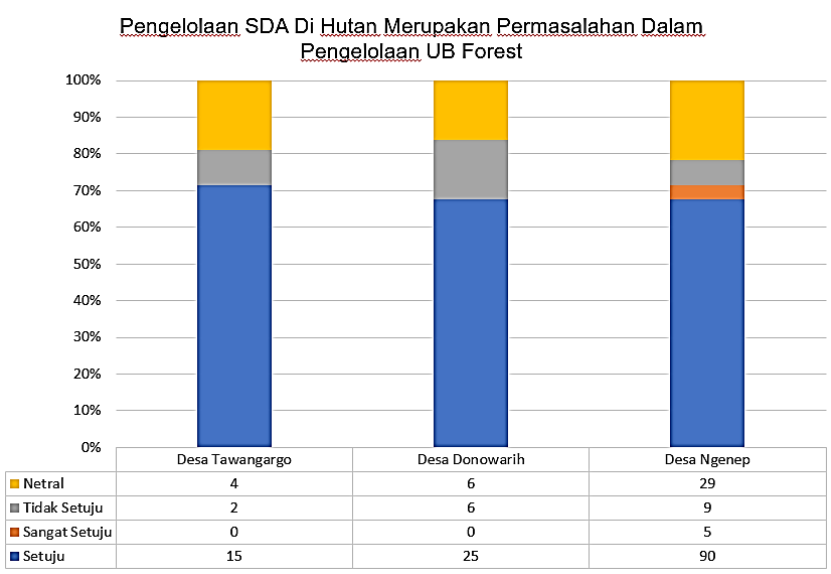

Gambar 5 Pengelolaan SDA di UB Forest merupakan Permasalahan dalam Pengelolaan Hutan

Sumber: Hasil analisis, 2020

\subsubsection{Letak Pengambilan Keputusan}

Letak pengambilan keputusan sepenuhnya ada pada pihak UB Forest, sudah baik dalam pelaksanaannya, yaitu memusatkan pengambilan keputusan pada pengelola utama pada UB Forest Manajemen. Untuk pengambilan keputusan sepenuhnya terpusat pada UB Forest.

Petani pesanggem, petani magersaren, dan masyarakat disekitar kawasan UB Forest hanya dilibatkan sedikit dalam pengambilan keputusan. Karena semua pengambilan keputusan terpusat pada UB Forest manajemen maka pengambilan keputusan cenderung bersifat otoriter. Pernyataan tersebut didukung dengan adanya data hasil survey dengan petani yang mengelola lahan UB Forest, sebagai berikut:

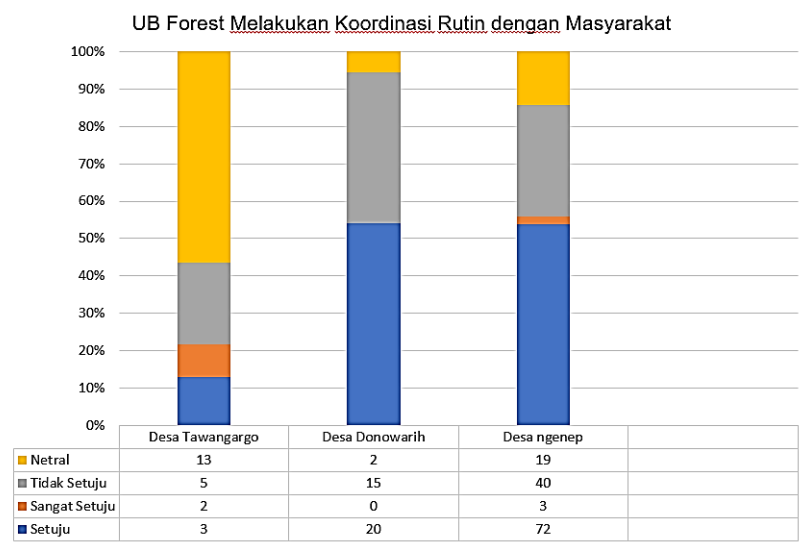

Gambar 6. UB Forest Melakukan Koordinasi Rutin dengan Masyarakat yang Tinggal Disekitar hutan UB Forest

Sumber: Hasil analisis, 2020

Adanya pengambilan keputusan yang terpusat sebenarnya terdapat sisi positifnya, yaitu memudahkan dalam hal koordinasi atau mengarahkan terkait pengelolaah kawasan UB Forest. Akan tetapi, masalahnya adalah kurang melibatkan partisipasi masyarakat dikawasan hutan pun mempengaruhi berhasil 
tidaknya implementasi dijalankan, berdasarkan hasil penelitian kurangnya pelibatan masyarakat dan komunikasi yang kurang baik akan menimbulkan implementasi hutan pendidikan di UB Forest memiliki resiko gagal yang tinggi atau sulit dilakukan.

\subsubsection{Pelaksana Program}

Implementasi tidak akan berjalan dengan baik jika tidak ada implementornya. Namun, faktor manusia juga menjadi kegagalan dalam pelaksanaan kebijakan, yaitu kurangnya pengetahuan dan pemahaman masyarakat dalam pengelolaan taman hutan raya tersebut. Sehingga dalam pelaksanaannya implementor harus paham terlebih dahulu dengan kemungkinan - kemungkinan yang terjadi atas pengelolaan hutan bersama masyarakat (Erlina dkk, 2018). Implementasi kebijakan hutan pendidikan di UB Forest merupakan pengelolaan hutan bersama masyarakat, karena hutan pendidikan UB Forest berdampingan dengan tempat tinggal masyarakat. Pelaksana program aksi atau kegiatan di UB Forest antara lain adalah UB Forest manajemen selaku pelaksana utama.

Sejauh ini UB Forest selaku implementor atau pelaksana program kegiatan menurut hasil wawancara dengan masyarakat sekitar hutan dan petani baik itu pesanggem maupun magersaren kurang kompeten dan belum bisa maksimal dalam komunikasi dan koordinasi dengan masyarakat. Kurang kompetennya kinerja UB Forest manajemen terhadap pengelolaan hutan mengakibatkan menurunnya perekonomian petani dan menimbulkan konflik yang terjadi antara UB Forest dan petani, bahkan masih akan terdapat beberapa konflik yang kemungkinan muncul dengan petani dalam pelaksanaan kebijakan ini. Sehingga kebijakan ini sulit dilakukan.

\subsubsection{Sumber Daya yang Digunakan}

Mengutip Edward III (1980) implementasi kebijakan harus ditunjang oleh sumber daya, baik sumber daya manusia, material maupun metoda. Sasaran, tujuan dan isi kebijakan meskipun sudah dikomunikasikan secara jelas dan konsisten, tetapi apabila implementor kekurangan sumber daya untuk melaksanakan, implementasi kebijakan tidak akan berjalan baik (Purwitasari, 2012).

Sudah jelas bahwa implementasi kebijakan tidak akan berjalan apabila tidak ada sumberdaya nya. Sumberdaya disini yang dimaksud adalah mengenai pembiayaan. Pembiayaan pada implementasi kebijkan hutan pendidikan di UB Forest berasal dari universitas dan penjualan produksi kopi (dapat dilihat pada Gambar 7).

Hasil pada ketiga desa disekitar UB Forest, memberikan pandangan bahwa sumber daya keuangan di UB Forest Manajemen kurang baik. Ketidakakuratan mengenai sumberdaya yang ada dalam pelaksanaan kebijakan ini. Belum adanya pengelolaan secara transparan dan terbuka tentang pembiayaan implementasi kebijkan ini, sehingga kebijakan hutan pendidikan di UB Forest cenderung mengalami kegagalan atu tidak berjalan sebagaimana mestinya.

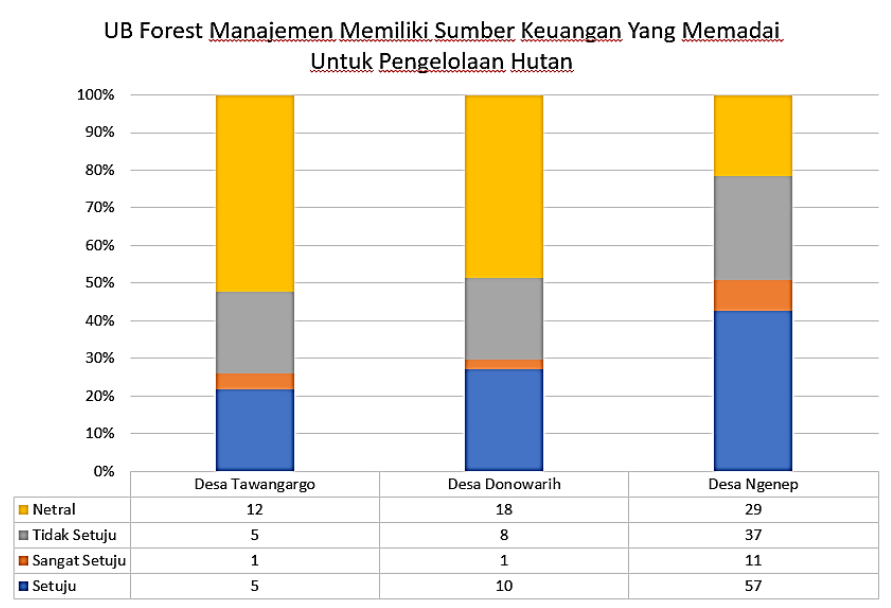

Gambar 7 UB Forest manajemen Memiliki Sumber Keuangan yang Memadai Untuk Pengelolaan Hutan Sumber: Hasil analisis, 2020

\subsubsection{Kekuasaan, Kepentingan, dan Strategi yang Digunakan}

Wakka (2014) pengaruh (power) masyarakat dalam pengambilan keputusan dalam pengelolaan KHDTK yang tergolong rendah dapat dilihat dari rendahnya kapasitas masyarakat (pengetahuan dan keterampilan, serta finansial terbatas). Disamping itu kekompakan masyarakat sekitar dalam menyuarakan kepentingannya yang juga masih sangat rendah. Kekuasaan, kepentingan, dan strategi yang dimiliki stakeholder yang terlibat dalam pengelolaan UB Forest, yaitu sebagai berikut:

a) UB Forest memegang kekuasaan tertinggi sebagai pengelola utama kawasan hutan, yang memiliki kepentingan untuk mengembangkan hutan sebagai lahan laboratorium yang bermanfaat untuk mahasiswa dan peneliti, dan juga memnafaatkan hasil hutan sebagai hutan produksi yang aktif. Saat ini pengelolaan kawasan hutan sebagai hutan produksi meliputi pengembangan hasil kopi yang dikelola langsung oleh UB Forest.

Pelaksanaan hutan pendidikan sebagai laboratorium lapang dengan strategi yang dilakukan oleh UB Forest adalah memasukkan beberapa matakuliah untuk fakultas pertanian yang bisa secara langsung memanfaatkan lahan hutan untuk praktikum dan pengambilan data rutin. Sebagai hutan produksi, UB Forest merubah pengelolaan yag sebelumnya produksi kayu dan getah, saat ini memproduksi kopi dan bekerjasama dengan petani yang sebelmnya sudah bekerja disana. 
b) Petani tidak memiliki kekuasaan yang berarti dalam pengelolaan UB Forest, karena mereka tidak memiliki lahan dihutan tersebut, sehingga kepentingan petani lebih pada agar pekerjaan yang sudah didapatkan atau dilakukan bertahun-tahun ketika dikelola perhutani tidak bergitu saja diputuskan. Meskipun tidak memiliki lahan di kawasan UB Forest, pekerjaan petani yang sebelumnya adalah petani kayu dan getah, saat ini menjadi petani kopi karena mengolah lahan di UB Forest.

Pada pengelolaan kopi, petani kurang setuju dengan sistem (desain) bagi hasil yang diberlakukan, sehingga mereka merasa dirugikan. Mulai dari sini banyak sekali aturan yang diterapkan oleh UB manajemen tidak lagi didengar oleh petani, seperti penjualan hasil kopi yang seharusnya pada UB Forest tapi petani lebih memilih menjual pada tengkulak.

c) Masyarakat sekitar kawasan hutan, masyarakat yang tinggal disekitar kawasan hutan memiliki kakuasaan dalam mempertahankan adat istiadat dan budaya mereka. Namun juga mereka memiliki kepentingan dalam menopang kehidupan sosial-ekonomi mereka sendiri. Mereka memanfaatkan lahan pekarangan rumah yang berada disekitar kawasan hutan untuk menanam beberapa macam sayuran, dan UB Forest tidak mempermasalahkan hal tersebut.

d) Mahasiswa dan peneliti, sebagai mahasiswa dan peneliti sudah pasti membuat karya ilmiah adalah hal yang wajib. Mereka memiliki kepentingan untuk memperkaya literatur penelitian yang nantinya dapat menghasilkan rujukan baik itu skala lokal, nasional, maupu internasional. Dengan adanya UB Forest mereka merasa diuntungkan karena memiliki lahan untuk melakukan penelitian dan mendapatkan laboratorium lapang, namun ini hanya untuk sebagian kecil mahasiswa/ pneliti yang sudah mengetahui UB Forest sebelumnya, khususnya pada Fakultas Pertanian UB.

Grindle (1980) menyatakan bahwa "frequently, the goals of the actors will be in direct conflict with each other and the outcome of this conflict and consequently of who gets what, will be determined by the strategies, resources, and power positions of each of the actors involve". UB Forest manajemen dan petani selaku aktor yang terlibat langsung pada pengelolaan kawasan hutan pendidikan memiliki kekuasaan, kepentingan dan strategi yang berbeda. Karena adanya kekuasaan, kepentingan, dan strategi para aktor berbeda maka kebijakan ini termasuk sulit dilakukan.

\subsubsection{Karakteristik dan Rezim yang Berkuasa}

Suatu lingkungan pada kebijakan yang diimplementasikan akan mempengaruhi berhasil tidaknya kebijakan tersebut, maka pada bagian ini akan dijelaskan karakteristik dari suatu lembaga yang akan turut mempengaruhi suatu kebijakan, yaitu kebijakan hutan pendidikan. Implementasi kebijakan dapat menimbulkan konflik pada kelompok-kelompok yang kepentingannya dipengaruhi. Pada akhirnya penyelesaian konflik akan menentukan siapa mendapatkan apa.

Rezim yang berlaku saat ini pada pelaksaan kebijakan terkait kehutanan merupakan rezim sentralistis. Dimana sebagian besar urusan daerah dipegang oleh pusat. Terutama pada pemanfaatan sumberdaya alam yang mana itu termasuk pada sumberdaya kehutanan. Pada pelaksananaan peraturan mengenai pemerintah daerah yang menjadikan pemerintah pusat sebagai aktor dominan dalam tata kelola kawasan kehutanan. Secara bersamaan pula seperti memberikan sebuah batasan yang hampir menyeluruh atas wewenang bupati dan walikota terkait tata kelola hutan.

Grindle (1980) mengatakan bahwa "the extend to which political regimes and administrative organizations have the power to implement policies the are committed to". Sejauh mana suatu rezim politik dan organisasi administratif memiliki kekuatan untuk melaksanakan kebijakan yang menjadi komitmennya. Dengan rezim sentralistis pelaksanaan kebijakan hutan pendidikan di UB Forest cenderung sulit untuk dilakukan.

\subsubsection{Tingkat Kepatuhan dan Responsivitas}

Kepatuhan dan ketanggapan meliputi keadaan pada lingkungan implementasi, agar tujuan kebijakan/ program tercapai sesuai dengan tujuan, maka para implementor atau stakeholder yang terlibat didalamnya harus memiliki ketanggapan akan kebutuhan - kebutuhan kelompok sasaran. Termasuk juga pada daya tanggap dalam menyelesaikan suatu konflik ketika implementasi kebijakan sedang berjalan.

Daya tanggap bisa disebut pula tingkat tanggung jawab dari pelaksana kebijakan, apabila tanggung jawab dalam pelaksanaannya rendah/ minim, maka akan mengakibatkan implementor kehilangan informasi dalam mengevaluasi pencapaian program dan akan mengalami krisis dukungan yang penting untuk mencapai keberhasilan program, baik itu dukungan dari kelompok sasaran maupun dari pelaksana kebijakan itu sendiri.

Mengutip Hogwood \& Gunn (1978) pihak-pihak yang memiliki wewenang kekuasaan dapat menuntut dan mendapatkan kepatuhan (Sulastri, 2009). Pernyataan tersebut menjelaskan bahwa harus terdapat kondisi ketundukan penuh dan tidak ada penolakan sama sekali terhadap perintah/ komando dari siapapun didalam sistem administrasi.

Pada implementasi kebijakan hutan pendidikan ini, UB Forest Manajemen bahkan belum memiliki aturan yang sah dalam pengelolaannya, sehingga kecenderungan untuk tidak patuh dan tidak bertanggung jawab semakin besar/ tinggi. Pada akhirnya hal tersebut mengurangi kepercayaan petani terhadap UB Forest, 
yang merupakan salah satu penyebab implementasi tidak berjalan dengan baik. Selain itu petani juga tidak patuh terhadap aturan-aturan yang diberikan UB Forest selaku pemilik tanah dikawasan tersebut. Hasil kopi yang dipanen tidak disetorkan kepada UB Forest melainkan dijual ke tengkulak di luar kewenangan UB Forest.

UB Forest memiliki keinginan untuk memfasilitasi petani-petani kopi dikawasan UB Forest, namun mereka memang memiliki keterbatasan mekanisme. Belum adanya sistem operasional prosedur yang secara khusus untuk mengatur pengelolaan UB Forest juga merupakan rendahnya tanggung jawab UB Forest.

\section{Kesimpulan}

Penelitian ini menyimpulkan bahwa:

a) Implementasi kebijakan hutan pendidikan di UB Forest belum memperlihatkan dampak dan perubahan pada masyarakat seperti yang diharapkan. Tujuan UB Forest belum bisa mendukung kesejahteraan masyarakat yang tinggal disekitar kawasan hutan. Selain itu juga tujuan tersebut belum dilaksanakan sesuai dengan desain yang sudah disepakati;

b) Belum tercapainya tujuan tersebut disebabkan oleh berbagai aspek baik dari isi kebijakan, yang meliputi: 1) Kepentingan yang dipengaruhi; 2) Tipe manfaat; 3) Derajat perubahan; 4) Letak pengambilan keputusan; 5) Pelaksana program, dan 6) Sumberdaya yang digunakan. Dan lingkungan implementasi, yang meliputi tiga aspek yaitu: 1) Kekuasaan, kepentingan, dan strategi dari aktor yang terlibat; 2) Karakteristik lembaga dan rezim yang berkuasa; 3) Kepatuhan dan responsibilitas.

\section{Daftar Pustaka}

Febrianto, A., \& Kusbandrijo, B. (2007). Pemberdayaan Masyarakat Melalui Kampung Binaan Mitra Astra (Studi Eksplanasi Tentang Pemberdayaan Melalui Kampung Binaan Mitra Astra RT 3 dan RT 4 RW 8 Kelurahan Keputih Kecamatan Sukolilo, Kota Surabaya). JPAP (Jurnal Penelitian Administrasi Publik), 1(1), 1-15.

Grindle, M. S. (1980). Politics and Policy Implementation in the Third World. New Jersey: Princeton University Press.

Hairiah, K., Sardjono, M. A., \& Sabarnurdin, S. (2003). Pengantar Agroforestri (Bahan Ajar Agroforestri 1). Bogor: World Agroforestry Centre (ICRAF).

Hero, Y., Tarumingkeng, R. C., Darusman, D., \& Kartodihardjo, H. (2012). Institutional Role in Gunung Walat Educational Forest Policy: Discourse and Historical Approaches. Jurnal Manajemen Hutan Tropika (Journal of Tropical Forest Management), 18(2), 94-99. https://doi.org/10.7226/jtfm.18.2.94
Jaenal, Enjen., Mulyadi A.T., \& Bambang Supriono. (2012). Pengelolaan Kolaborasi Hutan Pendidikan Dan Pelatihan Jampang Tengah - Sukabumi. Jurnal Nusa Sylva, 12, 9-24.

Johansson, J. (2018). Collaborative governance for sustainable forestry in the emerging bio-based economy in Europe. Current Opinion in Environmental Sustainability, 32, 9-16. https://doi.org/10.1016/j.cosust.2018.01.009

Lugina, M., Linda Ginoga Kirsfianti., Wibowo Ari., Bainnaura Afiefah., \& Partiani Tian. (2011). Prosedur Operasi Standar (SOP) untuk Pengukuran Stok Karbon di Kawasan Konservasi. Bogor: Pusat Penelitian dan Pengembangan Perubahan Iklim dan Kebijakan Badan Penelitian dan Pengembangan Kehutanan Kementerian Kehutanan, Republik Indonesia Kerjasama dengan International Tropical Timber Organization (ITTO).

Lundgren, B., \& Raintree, J.B. (1983). Sustained Agroforestry. In: Nestel, B (Ed.), Agricultural Research for Development: Potentials and Challenge in Asia. ISNAR, The Hague, Netherlands. 37-49. Print.

Moleong, L.J. (2011). Metodologi Penelitian KualitatifEdisi Revisi. Bandung: PT. Remaja Rosdakarya.

Mustofa, M. S. (2013). Perilaku Masyarakat Desa Hutan Dalam Memanfaatkan Lahan Di Bawah Tegakan. Komunitas: International Journal of Indonesian Society and Culture, 3(1), 1-11. https://doi.org/10.15294/komunitas.v3i1.2287

Nair, P. K. R. (1993). An Introduction to Agroforestry. Kluwer Academic Publisher, Dordrech.

Nugroho, R. (2017). Public Policy (Edisi Keenam). Jakarta: PT Elex media Komputindo.

Parsons, W. (2006). Public Policy: Pengantar Teori dan Praktik Analisis Kebijakan. Jakarta: Kencana.

Pramono, L. Y. J. (2014). Sejarah Penguasaan Hutan dan Pola Pemanfaatan Lahan oleh Masyarakat di Sekitar Kawasan Hutan KPHP Rawas Kabupaten Musi Rawas Utara. Jurnal Penelitian Ilmu-Ilmu Kehutanan, 3(1), 26-29. https://doi.org/10.1017/CBO9781107415324.004

Pressman, Jeffrey L., \& Aaron B. Wildavsky. (1973). Implementation: How Great Expectations in Washington are Dashed in Oakland-3rd ed. Berkeley: University of California Press.

Pulzl, H., \& Treib, O. (2006). Handbook of Publik Policy Analysis: Theory, Politics, and Methods (F. Fisher, G. J. Miller, \& M. S. Sidney, Eds.). USA: CRC Press.

Purwitasari, A.Y. (2012). Implementasi Kebijakan Program Jampersal di Kabupaten Lebak Propinsi Banten Tahun 2011. Tesis, Program Studi Ilmu 
Kesehatan Masyarakat. Depok: Fakultas Kesehatan Masyarakat, Universitas Indonesia.

Sabatier, Paul., \& Daniel Mazmanian. (1979). The Conditions of Effective Implementation: A Guide to Accomplishing Policy Objectives. Policy Analysis, 5(4), 481-504.

Sulastri. (2009). Analisis Implementasi Kebijakan Pendidikan Gratis Pada Sekolah Menengah Pertama (SMP) di Kabupaten Tangerang. Tesis, FISIP, UI, Depok.

Wahab, S. A. (2011). Pengantar Analisis Kebijakan Publik. Malang: UMM Press.

Wahab, S. A. (2017). Analisis Kebijakan: Dari Formulasi ke Penyusunan Model-Model Implementasi Kebijakan Publik (Edisi 1, Cetakan 6). Jakarta: Bumi Aksara.

Wakka, A. K. (2014). Analisis Stakeholders Pengelolaan Kawasan Hutan Dengan Tujuan Khusus (KHDTK) Mengkendek, Kabupaten Tana Toraja, Provinsi Sulawesi Selatan. Jurnal Penelitian Kehutanan Wallacea, 3(1), 47-56. https://doi.org/10.18330/jwallacea.2014.vol3iss1p $\mathrm{p} 47-55$

Widiyanto., Nurheni Wijayanto., \& Didik Suprayogo. (2003). Pengelolaan dan Pengembangan Agroforestri - Bahan Ajar Agroforestry 6. Bogor: World Agroforestry Centre (ICRAF) .

Zaini, M., \& Darmawanto, A. (2015). Implementasi Pembangunan Berkelanjutan Berwawasan Lingkungan Studi Pada Kelurahan Lempake Kecamatan. Jurnal Ilmu Ekonomi dan pembangunan (JIEP), 15(2), 24-31. 